\title{
Slovní druh jako základní jazykovědný a didaktický pojem
}

\section{Slovní druh jako základní jazykovědný pojem}

Slovní druh je jedním z důležitých základních jazykovědných pojmů. Historie mluvnictví potvrzuje, že je spjat se vznikem systematické mluvnice od jejího počátku. Gramatiky novodobých evropských jazyků přjímaly již propracované třídění slovních druhů z řecké a zejména $z$ latinské mluvnice. Přejímaly je i s názvy, které pak podle své jazykové povahy upravovaly. Stejně to probíhalo i v české mluvnici. Vydělení slovních druhů ovlivnila také filosofie hledáním základních kategorií skutečnosti (zejména metafyzika Aristotelova). Jazykové kategorie slovních druhů s těmito kategoriemi souvisejí, nejsou však s nimi totožné. Rozlišení slovních druhů podle latinské mluvnice se v české mluvnici udržovalo velmi dlouho. Posíleno bylo autoritativními mluvnicemi Josefa Dobrovského a později Jana Gebauera. Zůstával i jejich shodný počet, tj. devět: podstatná jména, př́davná jména, zájmena, číslovky, slovesa, př́slovce, předložky, spojky a částice, citoslovce. Teprve $\mathrm{v} 50$. letech minulého století se částice, do té doby řazené do společného slovního druhu se spojkami, vydělily jako samostatný slovní druh. Rozlišení deseti slovních druhů bylo obecně přijato a stanovuje se tak ve všech současných mluvnicích. Ve stejné době, kdy byly odděleny částice, se objevily návrhy na osamostatnění dalších slovních druhủ. Tyto návrhy byly ovlivněny ruskou mluvnicí, která v té době rozlišovala ještě další slovní druhy. Nejvážnější byl návrh na vydělení predikativ, a to především ze slovního druhu př́íslovcí, které fungují jako významové jádro př́sudku po slovese být: chladno, pusto, smutno, nabiledni, zima, tma aj.

Touto problematikou se u nás zabýval např. M. Komárek, který ve Sborníku vysoké školy pedagogické v Olomouci (Jazyk a literatura 1954: 1-25) uveřejnil 
článek $K$ otázce predikativa (kategorie stavu) v češtině. Pokusil se odpovědět na otázku, zda lze pro češtinu uznat existenci nového slovního druhu, tzv. kategorie stavu, jejiž existenci dokazují pro ruštinu někteří sovětští jazykovědci. Komárek dochází $\mathrm{k}$ závěru, že tento nový slovní druh $\mathrm{v}$ češtině také existuje, a nazval jej predikativum. Na jeho př́spěvek reagoval $\mathrm{v}$ časopise "Slovo a slovesnost" F. Trávníček (1956: 6-18), který podrobným rozborem Komárkových př́kladů ukazuje, že pokud by měla být Komárkova domněnka správná, musela by jím uvedená slova mít takové osobité vlastnosti, pro které by se vymykala z dosavadních slovních druhů, a proto by nebylo dobře možné zahrnovat je do slovních druhů dosavadních. $\mathrm{V}$ závěru konstatuje, že na základě rozboru uvedených př́kladů nelze mluvit o zvláštním, novém slovním druhu a že slova zahrnovaná Komárkem k predikativům plně zůstávají v rámci slovních druhů dosavadních.

V současné lingvistice se odlišují jako zvláštní skupina př́slovcí.

\subsection{Vymezení slovního druhu}

Slovní druhy jsou vymezeny na základě tří kritérií, která se někdy vzájemně doplňují, jindy si konkurují, ale žádné z nich samo o sobě nestačí k tomu, aby byla jednotlivá slova jednoduše přiřazena k př́islušným skupinám slov. Je to kritérium: sémantické (významové), morfologické (tvaroslovné) a syntaktické (skladební). Jak uvádí M. Čechová,

pořadí kritérií nevypovídá o stupni jejich důležitosti, ale ani o pořadí uplatňovaném při určování slovního druhu. Pořadí je voleno od méně abstraktního k nejabstraktnějšímu, od nižších jazykových rovin k rovině vyšší (Čechová 2000: 86).

\subsubsection{Vymezení slovního druhu z hlediska sémantického}

Z hlediska sémantického pohlížíme na slovní druhy jako na slova pojmenovávající různé druhy jevů reality. Podstatná jména, př́davná jména, slovesa a príslovce můžeme odvodit př́mo z pojmů našeho myšlení, jsou to slovní druhy základní, tvořící základ slovnědruhové soustavy a představující nejvyšší stupeň mluvnického zobecnění. Svými funkčními vlastnostmi je napodobují slovní druhy nástavbové: číslovky, zájmena a zájmenná př́slovce. Všechny tyto slovní druhy tvoří slova plnovýznamová, tzv. autosémantika. Plnovýznamová jsou i některá citoslovce, napodobující např. zvuky (prásk, cink) nebo označující psychické prožitky (juchú, ouvej, proboha). Nemají však pojmovou složku, mají pouze funkci vypovídající a expresivní. ${ }^{1}$ Ostatní slova, tj. předložky, spojky a částice, jsou slova neplnovýznamová, tzv. synsémantika. Jsou to slova významově závislá, která získávají plný význam až ve spojení s autosémantiky. Jejich hlavním úkolem je podílet se na výstavbě a organizaci textu.

\footnotetext{
${ }^{1}$ M. Čechová a kol., Čeština - řeč a jazyk, Praha 2000, s. 87.
} 


\subsubsection{Vymezení slovního druhu z hlediska morfologického}

Ani na základě morfologického kritéria (slova ohebná a neohebná) nelze všechna slova do slovních druhů rozdělit. Lze jej využít pouze u slov, která mohou své tvary měnit, tj. u slov ohebných. Ohebné slovní druhy se dále dělí podle způsobu ohýbání na slova, která se skloňují, tj. mají tvary podle pádů (podstatná jména, př́davná jména, zájmena a číslovky), a ta, která se časují (slovesa). Při určování ohebného slovního druhu je výrazným kritériem tvar slova. Na jeho základě řadíme podstatná a př́ídavná jména slovesná, která vykazují některé vlastnosti sloves (nap̌r. slovesný vid) ke jménům, protože je nečasujeme, ale skloňujeme (kreslení, nesení; kreslený, kreslicí, nesený, nesouci).

\subsubsection{Vymezení slovního druhu z hlediska syntaktického}

Toto hledisko uplatňuje zřetel k syntaktické funkci jednotlivých skupin slov. Nesamostatné slovní druhy, které významově plnovýznamové slovní druhy doplňují, primárně syntaktickou funkci nemají: předložky, spojky a částice. Předložky samy o sobě větným členem nejsou, ale vstupují do syntaktického vztahu společně se jmény (pod střechou — prísl. určení místa, v prosinci — př́sl. určení času, podle módy — prrísl. určení způsobu, čaj o páté — př́ívlastek neshodný, měl jsem ji za dámu — doplněk, myslel na ni — předmět), spojky spojují větné členy a věty. Částice stejně jako předložky a spojky větnými členy nejsou. Obvykle

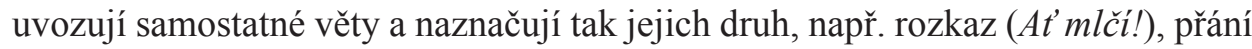
(Kéž se uzdraví.), zvolání (Kdybys nemluvil!), nebo vyjadřují stanovisko mluvčího k obsahu věty (V̌̌ak ty si ještě vzpomeneš).

Všechna uvedená hlediska se pak využívají v podání definic slovních druhů. Zcela základním rysem je však skutečnost, že rozdělení slovních druhů je jediný postup, kterým se roztřídí všechna slova slovní zásoby — každé slovo př́isluší k některému slovnímu druhu. Slovní druhy nejsou pevně ohraničené, nepropustné skupiny, ale existují četné př́pady přechodů slov z jednoho slovního druhu do druhého.

\section{Slovní druh jako didaktický pojem}

Postavení slovních druhů $v$ učivu českého jazyka vychází z jeho místa v jazykovém systému a odpovídá jeho závažnosti. Velký význam má v dnešní době znalost slovních druhů pro vyučování cizím jazykům. Např. znalost podstatných jmen umožní užívat $\mathrm{v}$ němčině slova s př́islušným členem a psát je velkými písmeny. Názvy slovních druhů je třeba chápat jako značky, označení pro slova mající uvedené charakteristické znaky. Mnohé vznikly v minulosti jako překlady latinských termínů, původ některých nelze vysvětlit ani etymologicky. Na základní škole, především na 1. stupni, doporučujeme užívat domáci termíny slovních 
druhů, s původními latinskými termíny můžeme žáky seznamovat postupně, např. v souvislosti s osvojováním cizích jazyků. Je to především z těchto důvodů:

— národní terminologii mají všechny slovanské jazyky — některé ji užívají zcela důsledně nejen pro školu, ale i ve vědě (např. ruština, slovinština; rovněž v polštině je užívána národní terminologie, a to i ve vysoce odborných publikacích, ${ }^{2}$ např. czasownik, spójnik aj.);

— v některých učebnicích češtiny se vedle českých termínů užívá i terminologie latinská, někdy však mylně označovaná jako mezinárodní. Žáci se na základní škole neučí latinský jazyk, neumějí proto termíny v náležitém tvaru používat (např. verbum, gen. sing. verbumu, nom. pl. verbumy); na 1. stupni se probírá jen pravidelné skloňování podstatných jmen — jestliže se žáci v komunikační praxi setkají s odchylkami od pravidelného skloňování, učitel jim př́slušný tvar vysvětlí, ale neprocvičuje jej; protože skloňování slov přejatých a cizích (obecných i vlastních) má řadu zvláštností, je tomuto učivu věnována větší pozornost až na 2. stupni $Z \check{S}$; i zde je však věnována s ohledem na jazykovou správnost pozornost takovým slovům, v nichž se často chybuje (např. slova obecná: datum, album, schéma aj., jména vlastní: upozorňujeme např. na slovanská př́jmení Gorkij, Tolstoj, Slowacki, která jsou původem př́davná jména a také se tak skloňují);

— učitelé vyučující cizí jazyk upozorňují praktikující studenty i vyučující vysokých škol na skutečnost, že žáci latinským termínům nerozumějí mnohdy ještě ani na stř̌ední škole; nejprve musejí tedy pochopit, že např. zájmena jsou slovním druhem, který zastupuje za jména, naučit se zájmena poznávat a teprve poté je možné uvést latinský termín pronomina;

- $\mathrm{s}$ latinskou terminologií se nepracuje ani v kurikulárním dokumentu pro základní vzdělávání, tj. RVP ZV, a po žácích její osvojení vyžadováno není.

Přestože se v současné době objevují hlasy volající po zavedení latinské terminologie do češtiny již na 1 . stupeň základní školy, opustit domácí termíny by rozhodně nebylo správné a zavést vedle nich (zvláště na 1. stupni) i terminologii latinskou je zbytečné zvyšování nároků kladených na žáky.

Poznání slovních druhů je základem pro pochopení spjatosti tvarů slov, předpokladem pro tvarosloví, v němž se žáci seznamují s uspořádáním soustavy skloňování a časování a se spisovnými tvary slov. Rozlišení slov na jednotlivé druhy ve 2. ročníku je vstupem k chápání mluvnice domácího jazyka, ale i jazyka cizího. Tomuto prvnímu kroku musí být proto věnováno dostatek času a promyšlený metodický postup. Postup rozlišování je v dalších věkových stupních s využitím myšlenkové vyspělosti žáků dále prohlubován a zpřesňován, pro posílení trvalosti poznatků i opakován. Obtížnost poznávání slovních druhů spočívá především $\mathrm{v}$ tom, že nejsou, jak jsme uvedli, rozlišeny podle kritéria jednoho, ale kombinací kritérií významového, tvaroslovného a skladebního. I když tento způsob dělení není dokonalý, je zatím jediný, na jehož základě můžeme roztř́ídit všechna slova slovní zásoby do skupin beze zbytku.

\footnotetext{
${ }^{2}$ Z. Zagórski, Spisane stowa formy i myśli, Poznań 2006, s. 48-61.
} 


\subsection{Metodický postup při osvojování učiva o slovních druzích}

V počátcích poznávání slovních druhů je nejvhodnější začínat hlediskem významovým, které postihuje, co daný slovní druh pojmenovává. Sémantická vymezení slovních druhů jsou sice zjednodušující, ale pro žáky tohoto věku v konkrétních př́ikladech snadno pochopitelná (napřr. podstatná jména jsou názvy osob, zvírat a věcí; označení věc používáme zpočátku i pro podstatná jména, jako hloupost, samota, lékařství (názvy vlastností), běh, kreslení, zápis (názvy dějů). Neustále se zachovává lingvistický prístup k problematice. Na základě tohoto hlediska vyvozujeme podstatná a př́davná jména, zájmena, číslovky, slovesa, př́slovce a citoslovce. U poznávání předložek, spojek a částic uživáme hledisko skladební, které opět aplikujeme velmi zjednodušeně. $Z$ hlediska tvaroslovného se uplatňuje zřetel k formě slova, $\mathrm{k}$ jeho tvaru. Hledisko postihuje, zda slovo svým tvarem vyjadřuje jmenné nebo slovesné kategorie (tj. zda je ohebné), nebo zda svým tvarem mluvnické významy nevyjadřuje (slovo je pouze $\mathrm{v}$ jedné podobě). Na základě tohoto poznání vyvodíme, že slova se rozlišují na ohebná a neohebná. Z uvedeného přehledu je zřejmé že poznávání slovních druhů nemůže mít charakter jednorázového učiva. Představuje proces spojený s poznáváním mluvnického systému a v návaznosti na tvaroslovné a syntaktické učivo je nutné $\mathrm{v}$ jednotlivých ročnících prohlubovat také uvědomělé poznávání slovních druhů. Zvláštní syntaktické a morfologické znaky úplné definice slovního druhu si žáci mohou uvědomit až v pozdějších ročnících na základě znalostí o větných členech a paradigmatech. $\mathrm{Na} 1$. stupni je hlubší pozornost věnována slovním druhům ohebným, na 2. stupni neohebným, učivo se dále prohlubuje, zpřesňuje a pro posílení trvalosti poznatků opakuje. Pro žáky je vyjmenování slovních druhů potřebné, jejich znalost patří k základnímu učivu. Dbáme na to, aby slovní druhy byly při reprodukci uváděny v určeném pořadí, které má svou vnitřní logiku. Nejprve jsou zařazeny slovní druhy ohebné, a to jména a slovesa. Na prvním místě jsou podstatná jména (1), nebot' označují základní skutečnosti, následují př́davná jména (2) označující vlastnosti, pak zájmena (3), která oba předchozí slovní druhy zastupují a číslovky (4) jako slova s významem počtu. Na páté místo jsou zařazena slovesa (5), a za nimi následují slovní druhy neohebné v pořadí př́slovce (6), předložky (7), spojky (8), částice (9) a citoslovce (10).

Výsledky výzkumu ${ }^{3}$ potvrzují, že poznání slovního druhu je pro žáky snadnější tam, kde vystupuje nápadně jeho specifický rys. Bývá to význam, např. u podstatných jmen (žák si snadno uvědomí, že názvy osob, zviřăa a věcí, včetně abstrakt, jsou podstatná jména), nebo forma, např. u př́ídavných jmen, která se vyjadřuje shodou s podstatnými jmény: milý člověk, milá vzpomínka, milí lidé. Při určování sloves se uplatňuje jak forma (kreslím, kreslí, kreslit), tak i význam (dějovost) a u př́slovcí je rozhodující pouze význam (např. misto, čas, zpưsob,

${ }^{3}$ K. Klímová, Slovni druhy v jazykovém vyučování, Brno 2005. Disertační práce. PdF MU. Vedoucí práce: Přemysl Hauser, https://is.muni.cz/auth/th/322/pedf_d/. 
přičina). Při definování slovních druhů je třeba rysy, které jsou pro daný slovní druh charakteristické, zdůraznit. Při zařazování některých slov ke slovním druhům často převládne forma, zatímco morfologický znak ustupuje do pozadí. Např. neurčité zájmeno nějaký má zakončení (formu) jako př́idavné jméno, proto k nim bývá často zařazováno. Do pozadí ustupuje skutečnost, že slovo vyjadřuje různé odstíny neurčitosti např. předmětu, vlastnosti nebo vlastníka, převládá tedy zřetel $\mathrm{k}$ formě. Podobně např. slovesa zakončená ve 3 . osobě jednotného i množného čísla dlouhou samohláskou -i (vidí, leží, spí apod.) jsou někdy žáky přiřazována k př́ídavným jménům, a to bez ohledu na skutečnost, že slovo vyjadřuje mluvnické kategorie osoby, čísla, způsobu, času, rodu a vidu. Jindy bývá odhadován druh slova podle jeho délky. Krátká slova jsou žáky určována často jako předložky, někdy také jako spojky, např. $t o, a t^{\prime}, u \check{z}, t u \ldots{ }^{4}$

Při poznávání slovních druhů působí v některých případech žákům potíže tvarová homonymie (např. se — zvratné zájmeno a předložka se 7. pádem) a někdy má dokonce pravopisné důsledky (Jardovi - 3. pád podstatného jména, vzor předseda; Jardovi kamarádi-Jardovy kamarády — 1. a 4. pád př́́davného jména přivlastňovacího). Této skutečnosti je třeba využít $\mathrm{k}$ zobecnění, že o slovnědruhové př́íslušnosti slova rozhoduje jeho konkrétní užití v textu. Vedle toho jsou i slova, jejichž slovnědruhová př́slušnost je složitá a někdy není v žákovských silách, aby o ní správně rozhodli. Jsou to např. slova málo, mnoho, kolik, tolik, která mohou být neurčitými číslovkami nebo př́slovci. V takových a podobných př́padech vedeme žáky k použití Slovníku spisovné češtiny pro školu a veřejnost (1994), př́ípadně Internetové přiručky.

S názorem, že lze mluvnici učit bez termínů, poznávat tvarosloví bez znalosti slovních druhů NELZE souhlasit. Odsouvat znalost někam do pozdějšího věku vede $\mathrm{k}$ učení jednotlivostem bez zřetele k systému. V seznamování se slovními druhy lze využít dvojí postup:

a) uvést hned zpočátku všech deset slovních druhů (jejich názvy a stručné definice);

b) seznamovat se slovními druhy postupně, odděleně a souhrn uvést až nakonec.

První postup byl jako výhodný ověřen dlouholetou školní praxí (postupovalo se tak vždy) a vychází i z psychických předpokladů žáků. Ve věku, kdy učivo poznávají, mají rozvinutou mechanickou pamět' a názvy všech slovních druhů si v podaném pořádku bez potíží osvojí. Je pak také větši záruka, že je v paměti podrží. Didaktika rovněž potvrzuje, že je výhodnější exponovat celek a pak jej dále rozčleňovat než jej z částí skládat. Tento v podstatě deduktivní postup odpovídá i postupu vědeckému. Induktivní budou jednotlivé kroky při odvozování. ${ }^{5}$

\footnotetext{
${ }^{4}$ Ibidem.
}

${ }^{5}$ Př́i poznávání slovních druhů je nutné upozornit žáky na to, že slovní druhy nemají přesně uzavřené hranice, ale že jednotlivá slova mohou přecházet z jednoho slovního druhu do jiného. Projeví se to jejich užitím ve výpovědi, ve změně významu a skladebné funkce. Náležitou představu 
Základní znaky slovních druhů poznávají žáci na 1. stupni podrobněji v pořadí: podstatná jména, slovesa, spojky, předložky, přidavná jména, čislovky, zájmena, príslovce, částice, citoslovce. Poučky si žáci neosvojují pamětně, ale osvojují si smysl termínů řešením daných úkolů.

Podávání učiva je stálý proces, vždy jej lze upravovat a zlepšovat, popř́ípadě přizpůsobovat novým vědeckým poznatkům a názorům. Rozdělení slovních druhů na ohebné a neohebné, které zatím běžně uvádějí učebnice jako jediné, je možné zařadit až po probírání charakteristik všech slovních druhů. Řadit slovo k slovnímu druhu lze provést také logickým postupem — algoritmem. Domníváme se, že na 1. stupni ZŠ není didakticky zcela vhodný úplný algoritmus, který uvádí Karel Svoboda. ${ }^{6}$ I když je velmi přesný, stálé užívání algoritmů by bylo zdlouhavé. Pokud však žák chybuje, můžeme použít algoritmus zjednodušený. Př́klad: slovo moudrost. Je to slovo ohebné nebo neohebné? Ohebné. Skloňuje se nebo časuje? Skloňuje se. Označuje počet nebo pořadí? Ne. Zastupuje jiné slovo nebo na něco ukazuje? Ne. Ptáme se na něj otázkami jaký, který, čí? Ne. Je to název osoby, zvířete, věci, vlastnosti nebo děje? Ano, je to název vlastnosti. Je to podstatné jméno.

Poznávání slovních druhů, jejich určování na izolovaných příkladech nebo $\mathrm{v}$ souvislém textu provádíme především $\mathrm{v}$ počáteční etapě osvojování pouze ústně. Ve školní praxi se občas objevuje snaha (potřeba) určovat druhy slov také písemně. Na úskalí, které je s tím spojené, upozorňoval P. Hauser. ${ }^{7}$ Jde především o stanovení toho, jak slovní druhy písemně zaznamenávat. Např. při všestranných jazykových rozborech, při nichž je větný celek nebo text napsaný na tabuli, se ve škole ujalo označování slovních druhů číslicemi jejich pořadí v souvislé řadě: podstatné jméno - 1, př́davné jméno - 2, zájmeno - 3... atd. (pro žáka je nejrychlejší napsat nad slovo číslici). I když toto značení není nejvhodnější, je tento způsob pro grafickou jednoduchost výhodný. Předpokládá však pevnou znalost zařazení, tj. spojení číslice se slovním druhem. Při počtu deseti slovních druhů se mohou žáci, zvláště v nižších ročnících, v označení mýlit. Mohou vědět, o který slovní druh jde, označí jej však nesprávným číslem. Není to tedy nedostatek v jazykovědných znalostech. Proto by pro vyloučení takových omylů měli mít žáci při určování tabulku s pořadím slovních druhů $\mathrm{k}$ dispozici. Při ústním zařazování slov ke slovním druhům je třeba také důsledně dbát na to, aby žák odpovídal jak pojmenováním slovního druhu, tak př́íslušnou číslicí. Např.: cvičí - sloveso 5, po - predložka 7, dlouhý - př́davné jméno 2 atd. Na základě dlouholeté praxe, a to na všech stupních škol včetně vysoké, mohu potvrdit, že pokud učitel tento způsob vyžaduje opravdu důsledně a hned od počátku, postupně se číslo a slovní

o povaze slovních druhů proto vytvoříme jejich poznáváním ve větné souvislosti. Určování slovních druhů u izolovaných slov využíváme jen pro demonstraci vhodných př́kladů a omezujeme je jen na počáteční seznamování s těmito pojmy.

${ }^{6}$ K. Svoboda, Didaktika českého jazyka a slohu, Praha 1977.

${ }^{7}$ P. Hauser a kol., Didaktika českého jazyka pro 2. st. ZŠ, Brno 2007, s. 71. 
druh v paměti žáků fixuje. Místo číslic je možné pro písemné zařazení slova k příslušnému slovnímu druhu použít i zkratky, které doporučuje V. Podhorná: podst., príd., zájm., čísl., sl., prìsl., předl., sp., část., cit. ${ }^{8} \mathrm{~S}$ tímto způsobem označování jsem se však zatím v praxi nesetkala, a to ani jako žák, ani jako učitelka. Je to zřejmě způsobeno skutečností, že tyto zkratky jsou pro písemné zaznamenávání poměrně dlouhé.

\section{Slovní druhy a současný kurikulární dokument}

Důležitost pojmu slovní druh vyžaduje jeho časté opakování, procvičování a prohlubování, aby znalosti byly opravdu trvalé. „Ž́ákovo myšlení rozvíjíme mj. trénováním různých myšlenkových operací, včetně zvratných (např. při určování slovních druhů si všímáme jejich funkcí ve větě a naopak u větných členů způsobu jejich vyjádření slovními druhy) [...].“9 Za základní jsou považovány analýza a syntéza, protože probíhají téměř v každé myšlenkové operaci žáka.

V současném kurikulárním dokumentu pro základní vzdělávání, v RVP ZV, je každé učivo stanoveno tzv. očekávanými výstupy (dále: OV). Jejich obsah konkretizují na konci prvního a druhého stupně tzv. Standardy pro základní vzdèlávání, které MŠMT ČR zařadilo jako př́lohu kurikulárního dokumentu s platností od 1. záríi 2013. Ty stanovují minimální úroveň obtížnosti OV na konci 5. a 9. ročníku, a jejich plnění je závazné. Minimální úrovně je třeba dosáhnout se všemi žáky na konci 5. a 9. ročníku. S platností od 1.9.2016 byly pro obory Český jazyk a literatura, Cizí jazyk a Matematika zveřejněny tzv. Metodické komentáre ke Standardìm pro základni vzdělávání, které obsahují ilustrativní úlohy a metodické komentáŕe k nim. Byly vytvořeny na základě Bloomovy taxonomie kognitivních výukových cílů založených na myšlenkových operacích a mají tři úrovně obtižnosti: minimální, optimální a excelentní. Jsou však pouze názorné, tzn. že učitel je použít může, ale nemusí. Jednotlivé úlohy doplňuje komentár speciálního pedagoga, který posuzuje a upozorňuje, jak řešit jednotlivé úlohy s žáky se specifickými poruchami učení. Smyslem těchto úloh je napomáhat učitelům při naplňování cílů vzdělávání stanovených v RVP ZV. V souvislosti s obsahem článku uvádíme ukázku zpracování očekávaného výstupu zaměřeného na slovní druhy, a to včetně indikátorů a ilustrativních úloh pro minimální, optimální a excelentní úroveň.

${ }^{8}$ V. Podhorná, Uživáme symboli̊ při vyučováni českému jazyku vždy funkčně?, Komenský 104, 1979/1980, s. 109-103.

${ }^{9}$ M. Čechová, Některé předpoklady osvojováni poznatků z českého jazyka, Český jazyk a literatura, Praha: SPN, a. s., 2005-2006, nr 56, s. 159. 


\begin{tabular}{|l|l|}
\hline Vzdělávací obor & Český jazyk \\
\hline Ročník & 5. \\
\hline Tematický okruh & Jazyková výchova (slovní druhy) \\
\hline $\begin{array}{l}\text { Očekávaný výstup } \\
\text { RVP ZV }\end{array}$ & $\begin{array}{l}\text { ČJL-5-2-03 } \\
\text { Žák určuje slovní druhy plnovýznamových slov a využívá je } \\
\text { v gramaticky správných tvarech }\end{array}$ \\
\hline Indikátory & $\begin{array}{l}\text { 1) žák zařadí vyznačené plnovýznamové slovo z textu ke slovnímu } \\
\text { druhu (podstatné jméno, přídavné jméno, sloveso, príslovce) } \\
\text { 2) žák vybere z krátkého textu větu, která obsahuje/neobsahuje zadaný } \\
\text { slovní druh } \\
\text { 3) žák použivá v mluveném i psaném projevu náležité tvary podstatných } \\
\text { a př́davných jmen (kromě pravopisu př́davných jmen přivlastňovacích) } \\
\text { 4) žák používá v mluveném i psaném projevu náležité tvary sloves ve } \\
\text { způsobu oznamovacím }\end{array}$ \\
\hline
\end{tabular}

První dvě myšlenkové operace (zapamatování a porozumění) se staly základem ilustrativních úloh pro minimálni úroveň. $\mathrm{V}$ úlohách $\mathrm{v}$ rovině zapamatování jde o vybavení a reprodukci dřive získaných informací nebo jejich rozpoznání.

\section{— MINIMÁLNÍ ÚROVEŇ \\ 1. S poctivostí nejdál dojdeš.}

\section{Zvýrazněné slovo ve větě je:}
a) podstatné jméno
b) př́slovce
c) př́́davné jméno
d) sloveso

\section{Která z následujících vět neobsahuje přídavné jméno?}

a) Hlavní město naší republiky je Praha.

b) Můj kamarád Petr běhá nejrychleji z celého mužstva.

c) Cestovatel vyprávěl zážitky z cest velmi zajímavě a poutavě.

d) V pět hodin vysílají v televizi velmi zajímavý cestopisný film.

\section{Rozhodněte, ve které z vět není spojení podstatného a přídavného jmé-} na pravopisně správně?

a) Žabí stehýnka jsou vyhlášená pochoutka.

b) Noví žáci se ve třídě rychle spruátelili.

c) Hluchý lidé potřebují naši pomoc.

d) V zoologické zahradě se vylíhla sokolí mlád'ata.

Pro stanovení optimální úrovně byly využity další dvě myšlenkové operace, a to aplikace a analýza. Pokud mají žáci aplikovat, znamená to, že si musejí vybavit informace, kterým rozumějí, a použít je v nové situaci. Pokud žáci znají zna- 
ky jednotlivých slovních druhů, prokáží schopnost aplikace ve chvíli, kdy obdrží neznámé texty, a jejich úkolem je např. poznat, který slovní druh je v ukázce zastoupen nejčastěji, a který naopak chybí. Analýza je založena na postupu od celku $\mathrm{k}$ jeho částem, a žáci se $\mathrm{v}$ ní postupně zdokonalují a cvičí. Analýza předpokládá: 1. znát znaky jevi̊, 2. ujasnit si jejich logickou strukturu, 3. podle této struktury znaky identifikovaného jevu ověřovat. Analytická jsou ve své podstatě cvičení vyhledávací, doplňovací, obměňovací, určovací a rozborová. Žáci mohou také porovnávat dva celky a hledat, co je pro ně společné a čím se liší, nap̌r. slova ohebná a neohebná, podstatná jména a prŕ́davná jména aj. Zde doporučujeme napřs. využití jedné z metod kritického myšlení, a to Vennových diagramů.

\section{— OPTIMÁLNÍ ÚROVEŇ}

1. Rozhodněte, ke kterým slovním druhům zařadíte podtržená slova. Který slovní druh je zastoupen mezi podtrženými slovy nejčastěji, a který naopak chybí?

Hořelo. A Vilém se loudal $\underline{s}$ balením svých pěti švestek. Tatínek se zlobil. „Vždyt' neví, čí je,“ prosila za Viléma maminka. Ptali jsme se tedy Viléma, čí je. Jemu se to však vykouřilo $\mathrm{z}$ hlavy. $Z$ uší mu ještě stoupaly obláčky dýmu. Hasiči $\mathrm{s}$ hadicemi už přibíhali, ale rodiče mleli z posledního: „Smůla se nám lepí na paty.“ A opravdu: pryskyřice z podlahy s žárem rozehřála! „Dnes už nevytáhneme paty z domu." Po tatínkových slovech nám naskočila husí kůže. Vilémovi místy i s husími brky. Najednou vyšla z požáru teta Bláža. Hrála všemi barvami. Byla u nás pečená vařená, úplně jsme zapomněli, že je u nás na návštěvě.

Podle Z. Svěráka: Jaké je to asi v Čudu

\section{Navrhněte, na základě kterého tř́ídicího znaku lze podtržená slova v textu uspořádat do dvou skupin.}

3. Prokažte, zda následující tvrzení je, či není pravdivé.

$\mathrm{V}$ textu je použito pět př́idavných jmen.

$\mathrm{ANO}-\mathrm{NE}$

\section{Slova v závorkách uved’te ve správných tvarech.}

Lesník pan Kolesa si vyšel do (les). Kráčel podle (skály — č. množ.), cesta klesala a pak zase stoupala až k (horské) plesu. Lesník radostně zatleskal: „Krásné polesí! Hotový prales!“

Ale vtom (zablesknout se) a kapky deště (zapleskat) o (lesklý) hladinu. „Honem do úkrytu!“" zvolal pan Kolesa, ale zakopl v klestí. V (kotník) ucítil (prudká) bolest. Ani nehlesl, (zatít) zuby a odkulhal domů.

„Já jsem se (těšit) na dnešní ples, a ted’ abych kvưli (ty) plesnivěla doma,“ zlobila se paní Kolesová. 
„Třesky plesky,“ opáčil lesník, „na mysliveckém plese (nesmět) Kolesovi chybět!“ A (jít). Paní Kolesová noblesně a pan Kolesa vedle ní pajdal. Že to je ale statečný chlapík?

Podle J. Žáčka: Nesedejte na ježka!

Základem nastavení poslední, tzv. excelentni úrovně, se stala syntéza a hodnocení (hodnotící posouzení). Syntézou rozumíme vytváření celku z jednotlivých částí. Je kreativní a vyžaduje znalost, která vyústí v samotném užívání. K syntetickým cvičením řadíme např. cvičení konstrukčni a přeměňovací. Jakmile si nap̌r. žák v nižších ročnících osvojí podstatná jména, přídavná jména, slovesa a př́íslovce, může tvořit věty, jejichž součástí jsou právě tyto slovní druhy.

\section{— EXCELENTNÍ ÚROVEŇ}

1. Přečtěte si pozorně následující text. Poté napište přehled všech slovních druhů a ke každému $\mathrm{z}$ nich vyberte $\mathrm{z}$ textu jeden př́klad. Použil autor všechny slovní druhy?

Hořelo. A Vilém se loudal s balením svých pěti švestek. Tatínek se zlobil. „VŽdyt' neví, čí je,“ prosila za Viléma maminka. Ptali jsme se tedy Viléma, čí je. Jemu se to však vykouřilo $\mathrm{z}$ hlavy. Z uší mu ještě stoupaly obláčky dýmu. Hasiči s hadicemi už přibíhali, ale rodiče mleli z posledního: „Smůla se nám lepí na paty.“ A opravdu: pryskyřice z podlahy s žárem rozehřála! „Dnes už nevytáhneme paty z domu." Po tatínkových slovech nám naskočila husí kůže. Vilémovi místy i s husími brky. Najednou vyšla z požáru teta Bláža. Hrála všemi barvami. Byla u nás pečená vařená, úplně jsme zapomněli, že je u nás na návštěvě.

2. Navrhněte věty podle uvedeného modelu (číslo označuje slovní druh). Slova mohou být $\mathrm{v}$ různých tvarech a čísle.
a) $7-1-5-2-1$.
b) $5-3-1$ ?
c) $1-8-1-5-2-1$.

\section{Slova v závorkách uved'te ve správných tvarech.}

Kdo z (my) by si pamatoval, co dělal třeba před (měsíc), před (rok), nebo dokonce před (několik) roky? Co ten den zažil, co se přihodilo ve (škola), doma, v okolí, s (kdo) a o (co) (zajímavý) hovořil, jakou tenkrát (číst) knížku, jaký film (vidět), jaké (být) počasí? Je zajímavé vzít si do (ruka) deník psaný třeba před (tři) roky a začít si v (on) číst. (Moct) si tak v duchu vyvolat události dávno prožité, na které bychom si jinak už ani nevzpomněli, a (moct) si znovu oživit kterýkoliv dávný den. 
Hodnoceni (hodnotici posouzeni) tvoří nejvyšší úroveň Bloomovy taxonomie. Žáci vyjadřují svůj názor např. na ověřovaný postup, nápad, vybírají z nabídky možnost, která je podle jejich uvážení nejlepší, seřazují více položek do hodnotového žebřričku apod. Žák musí být zadáním veden $\mathrm{k}$ tomu, aby svou volbu vysvětlil, aby argumentoval, jeho úkolem je srozumitelně sdělit všechny důvody, které ho vedly k dané volbě. Např.:

Porovnejte podtržená slova ve dvojici vět a určete jejich slovní druh. Své rozhodnutí vysvětlete a porovnejte s ostatními.

a) Petr vjel rychle kolem do garáže. - Až půjdeš kolem, určitě se zastav.

b) $\mathrm{Na}$ mezi konečně rozkvetly fialky. — Jaký věkový rozdíl je mezi tebou a sestrou?

c) Během odpoledne se přihnala bouřka. - V dobré kondici se udržoval během.

Učí se také hodnotit jak svoji práci, tak práci svých spolužáků. Např.:

a) Úkol jsem splnil/a bezchybně; zapomněl/a jsem na...; nevědělla jsem, že...; úkol se mi nepovedl, protože...; ještě si musím zopakovat...; všechny stylistické nedostatky se mi podařilo vhodně odstranit; přehlédl/a jsem...; potiže mi dělalaly větaly...aj.

b) Co se ti na práci spolužáka líbilo, co ti připadalo zajímavé, jaký máś celkový dojem z jeho práce; za co spolužáka pochváliśs, co mu doporučíš ke zlepšeni aj.

Je třeba zdůraznit, že všechny uvedené myšlenkové operace jsou vzájemně spjaty. Při volbě mezi různými možnostmi probíhají nejen procesy rozhodování, ale také citové procesy a stavy, jako je např. napětí, neklid, radost z nalezeného řešení apod. Při tvorbě nových učebnic českého jazyka, a to jak pro první, tak pro 2. stupeň, je třeba výše uvedené skutečnosti zvážit, a to jak při vyvozování jednotlivých slovních druhů, tak i dalšího učiva. Nároky kladené na žáka by měly být stupňovány přiměřeně, a to právě vzhledem $\mathrm{k}$ úrovni myšlenkových operací žáka.

\section{Shrnutí}

Slovni druh se jako jazykovědný pojem uplatňuje v nejdůležitějších jazykovědných disciplínách — v morfologii i lexikologii s tvořením slov a syntaxi, důležitou úlohu má i ve výcviku stylistickém a obecně komunikačním, velký význam má v dnešní době znalost slovních druhů pro vyučování cizím jazykům. Proto stojí učivo o slovnich druzich na počátku jazykového vyučování a celé je prostupuje. Je to učivo mnohostranné a pro žáky obtížné; jednak z toho důvodu, že při rozdělení slov do jednotlivých slovních druhů je třeba uplatnit tři kritéria (hlediska), 
jednak proto, že netvoří pevně ohraničené skupiny a existují četné př́ípady přechodů slov z jednoho slovního druhu do druhého. Proto je třeba věnovat podání učiva náležitou pozornost, neustále jej procvičovat, upevňovat a na 1. stupni pracovat především s jednoznačnými př́iklady. Opustit domáci termíny by proto rozhodnè nebylo správné a zavést vedle nich (zvláště na 1. stupni) i terminologii latinskou je zbytečné zvyšováni nároků kladených na žáky.

Slovní druhy poskytují prrístup k poznání praktických postupů užitých při jejich osvojování a míra tohoto osvojení je i mírou úspěšnosti jazykové výchovy.

\section{Bibliografie}

Brabcová R., Didaktika českého jazyka, Praha: SPN 1990.

Čechová M., Některé předpoklady osvojováni poznatků z českého jazyka, Český jazyk a literatura 2005-2006, nr 56, s. 157-163

Čechová M. a kol., Čeština — řeč a jazyk, Praha: SPN — ped. nakladatelství, a. s. 2011.

Grepl M. a kol., Př́ručni mluvnice češtiny, Praha: Lidové noviny 1995.

Hauser P., Klímová K. a kol., Didaktika českého jazyka pro 2. st. ZŠ, Brno: MU 2007.

Klímová K., Slovni druhy v jazykovém vyučování, Brno 2005. Disertační práce. PdF MU. Vedoucí práce: Přemysl Hauser, https://is.muni.cz/auth/th/322/pedf_d/.

Klímová K., Altmanová J. a kol., Metodické Komentáře ke Standardům pro základni vzdělávání, Praha: NÚV 2015, http://clanky.rvp.cz/clanek/c/Z/20713/metodicke-komentare-ke-standardum-zvcesky-jazyk-a-literatura.html/.

Komárek M., K otázce predikativa (kategorie stavu) v češtině, Jazyk a literatura 1954, s. 7-25.

Peciar Š., Niektoré problémy klasifikácie neohebných slov. In: Studie ze slovanské jazykovědy, Praha: SPN 1958, s. 141-146.

Podhorná V., Uživáme symboli̊ při vyučováni českému jazyku vždy funkčně?, Komenský 104, 1979/1980, s. 109-103.

Svoboda K., Didaktika českého jazyka a slohu, Praha: SPN 1977.

Štícha F. a kol., Akademická gramatika spisovné češtiny, Praha: ACADEMIA 2013.

Trávníček F., K otázce slovních druhů v češtině, Slovo a slovesnost 1956, nr 17 (1), s. 6-18.

Zagórski Z., Spisane stowa, formy i myśli. Studia z lat 1955-2001, Poznań: Poznańskie Studia Polonistyczne 2006. 